\title{
Carrying out the Principle of Horizontal Connectedness and Professional Justification in the Planned Curriculum for Kindergartens in the Field of Music Education
}

\author{
Olga Denac \\ Department of Pre-School Education, University of Maribor, Maribor, Slovenia \\ Email: Olga.Denac@um.si \\ Received 15 July 2015; accepted 9 October 2015; published 13 October 2015 \\ Copyright (C) 2015 by author and Scientific Research Publishing Inc. \\ This work is licensed under the Creative Commons Attribution International License (CC BY). \\ http://creativecommons.org/licenses/by/4.0/ \\ (c) (i) Open Access
}

\begin{abstract}
The article presented the results of a study which included 159 pre-school teachers from all over Slovenia. The aim of the research was to determine whether teachers in the process of operative planning of the educational process account for the principles of horizontal integration and professional justification. We analyzed the planned curriculum in terms of structure, activities, goals, principles and contents. The results of the research show that the music education has been losing professional autonomy within the field of art, as kindergarten teachers only partially carry out individual principles of the curriculum in the planning of the educational process.
\end{abstract}

\section{Keywords}

Curriculum for Kindergartens, Principle of Horizontal Connectedness and Professional Justification, Planning of the Educational Process, Music Education

\section{Introduction}

\subsection{Philosophical Basis of Music Education}

The field of music education is in the theory and practice of planning the curriculum associated with various notions (aesthetics, aesthetic education, education in the arts) and interpretations of the field of education. In the 
broader sense, the notion of aesthetics is not limited merely to art, but is also treated as a dimension of experience in any field in the curriculum. Dewey (1934) and Reid (1986) claim that experiences in music, fine arts, dancing as well as mathematics, history and other fields include the aesthetic component. Indeed, in the narrower sense the aesthetic is usually associated merely with the arts. Phenix (1964) claims that different types of art together constitute an independent area of aesthetic experience, a special category of comprehension which is of major significance in the development of human consciousness. Abbs (1994), too, claims that the aesthetic dimension is directly associated with experience in the arts and that it combines the perceptive, affective and cognitive levels in a unique manner. The arts represent a field of dynamic energy transferred through the processes of experiencing, perceiving and creating. Many authors, however, disagree with this theory. Best (1992) is of the opinion that there is no logical explanation to activities such as painting, playing on instruments, creating prose having a common cognitive dimension, since it is impossible to equally treat musical processes and processes in other fields of art. According to Elliott (1995) unifying the field of music with other fields of art would mean the destruction of its essence. Gardner (1995), too, in his theory of multiple intelligences suggests that it is impossible to speak of intelligence as a unified characteristic of the human mind, but rather of various types of intelligence. He defines music as a separate intellectual ability, since the principle music operations or components of musical intelligence are not directly related with the principle operations of other fields.

In theory, two opposing theses thus exist of the nature of art or of aesthetic experience, respectively. The philosophical standpoint of theoreticians claiming that different art forms constitutes a common generic essence can in the theory and practice of planning the educational process raise doubt in the necessity of the existence of individual fields of art in the curriculum. The philosophical standpoint of theoreticians who emphasize the autonomy of individual artistic fields ensures the autonomy of individual fields also in the curriculum. In the Slovene curricular space, the field of music is in the curriculum for primary and grammar school education defined as an independent subject field with established general and operative goals of music education as well as the contents and the standards of knowledge, while in the curriculum for kindergartens the field of music is merely a constituent part of the field of the arts in which all art varieties (music, fine arts, dancing, audio-visual arts and drama) are defined only in terms of global goals for the whole field, while individual fields of art are defined in terms of activities. Music education is thus in the curriculum for kindergartens defined as a constituent part of the field of art. Already Elliott (1995) pointed out that music when united with other fields of art could lose its autonomy. This is why the knowledge of the philosophical bases for the development of the curricula for music education, already due to the structure of the curriculum for kindergartens which do not anticipate the goals and contents of music activities, is so important for ensuring professional autonomy of the field of music in the planned and executory curriculum.

\subsection{The Pedagogical-Didactic Starting-Points of Music Education}

The principles defined in the curriculum for kindergartens are the basis for the planning, realization and evaluation of the educational process of music education. The way the pre-school teachers understand, interpret and eventually also realize them in practice to a large extent depends on the knowledge of psychological and pedagogical-didactic starting points of music education. In the following, some principles defined in the curriculum for kindergartens will be examined from the point of view of the subject field of music education.

\subsubsection{The Principle of Horizontal Connectedness}

At the level of planning and realization teachers should take into consideration the integration of different fields of activity (inter-subject connections) and with this also the various aspects of the children's development and learning (Curriculum for Kindergartens, 1999). Since the experiencing and comprehension of the present and the future time in the world are an inseparable whole to the child, teachers should in their planning of the educational process consider the unity and harmony and integration between individual fields of the child's development. This methodical principle should in the pre-school practice be planned in such a manner that it does not neglect the autonomy of individual subject fields, but rather includes their natural intertwining both in terms of content and from the point of view of the child's development and learning. Integration does not necessarily condition an equal representation of areas of activity in individual didactic units. An area of activity can be either superior or inferior compared to other subject fields.

Experience shows that cross-subject integration allows pupils to develop interest and motivation for learning 
and to deepen their understanding and use of knowledge. Besides this, they achieve higher grades, develop better interpersonal relationships and motivation for learning, and demonstrate self-confidence, mutual cooperation and understanding; they are also able to better recall and understand the learning materials and can transfer the acquired knowledge and abilities between different subject areas (Bevc, 2005; Sicherl-Kafol, 2007). Although cross-subject integration in Slovenia is still to be fully accepted professionally, research suggests that it is already often present in teaching (Denac \& Čagran, 2012).

Comparative aesthetics deals with the integration of artistic fields. In the educational process it justifies the correlation which is geared towards the content, and the correlation which is directed towards the process. The content aspects of the integration encompass the contents of various fields into thematic wholes, while the process aspect of the integration focuses on the process of perception, experiencing and expression. Both types of correlation should account for the general and specific characteristics of the individual artistic field.

\subsubsection{The Principle of Professional Justification of the Curriculum}

In the planning, realization and evaluation of the curriculum of the educational process the pre-school teacher accounts for the specific characteristics of the development and learning of pre-school children and for the differences regarding age groups and the findings of scientific disciplines defining the individual fields of activity in the kindergarten (Curriculum for Kindergartens, 1999). The basis for planning the educational process is a sound knowledge of the developmental principles in children. Only on the basis of such knowledge is it possible to define the tasks and goals for the individual age group. As an answer to the question which is the level of congruency between the general development of abilities and the musical development of abilities the authors (Radoš-Mirković, 1983; Moog, 1968; Hargreaves, 1986) state that in many cases the stages of development present merely a frame (work), since specific musical abilities show earlier in the case of some children and later in the case of others. And this requires individual treatment of musical development.

The formation of musical-subject goals at the level of planning the curriculum is of vital importance in the systematic monitoring of the musical development in children and also for ensuring professional autonomy in the field of music. In the process of operative planning it is necessary in the formation of musical-subject goals to start from the general principles of the curriculum and the global goals defined by specific fields. If the general and the field-specific goals of the curriculum are not accounted for and are subjected to specific musical-subject goals, such an act can frequently result in the fact that children lose interest and pleasure in music activities. Another type of danger can occur if attention is paid only to general and field-specific goals thus causing individual artistic fields to lose their autonomy. One should, however, be aware that the autonomy of individual fields of art can in the curriculum be maintained only through systematically set professional-subject goals, methods and contents of work.

\section{Research}

On the basis of the facts mentioned above the Department of pre-school education and the Faculty of Education, University of Maribor, carried out a research entitled The influence of the curriculum on the educational process in kindergartens in the field of the arts. The vastness of the study has demanded that the present paper is limited to some of the study questions in which the planned curriculum for the field of music education was analysed more in detail.

\subsection{The Goals of the Study and Research Questions}

The goal of the research, the results of which were obtained through the analysis of the planned curriculum was to establish the place and the role music education has in the curriculum for kindergartens and to what extent the pre-school teachers in the planning of music education take into account the principles of horizontal connectedness and professional justification.

Two general research hypotheses were formulated, namely:

- The field of music education in the planned curriculum is losing its professional autonomy,

- The pre-school teachers in the planned curriculum in the field of music education only partially realize some of the principles of the curriculum.

The hypotheses were tested in the framework of the following research questions:

How and to what extent does the integration between music activities and other areas of activity take place? 
To what extent and how are the global goals of the curriculum, the goals of the curriculum and the general and music-subject goals shaped by the pre-school teachers represented?

\subsection{Research Method}

The basic research method is the descriptive and causal-non-experimental method of empirical pedagogical research.

\subsection{Basic Population and Sample}

The basic population consists of the pre-school teachers in kindergartens throughout Slovenia who carried out the educational process in kindergartens for various age groups (from the age of 1 year to the age of 6).

The sample for the research consisted of 36 randomly chosen kindergartens. 159 pre-school teachers agreed to participate in the research. The majority of them had completed secondary school education (61.6\%), had the title of mentor (50.9\%), a past working period of more than 20 years $(62.3 \%)$ and performed work and tasks in the second age period, namely with children from 3 to 6 years of age (65.4\%).

\subsection{Collecting and Processing of Data}

180 letters describing the intent of the research were sent to the kindergartens. The pre-school teachers who agreed to participate in the research returned the lesson plans for the educational work of a three month period in the time agreed upon. Due to the specific nature of the planning the curriculum in kindergartens (weekly plans, monthly plans, groups of topics) the lesson plans comprised all the fields of activity included in the curriculum. The lesson plans were for the field of music education analyzed from the point of view of structure, activities, principles, goals, contents, methods and means for work.

The data were processed by means of the frequency distribution of variable (f, f\%).

\subsection{Data Analysis}

\subsubsection{How Do Teachers Integrate Various Activities among Each Other?}

In most cases the teachers integrate music activities with the field of teaching to dancing (and fine-arts education. These are followed by the field of language, social sciences, movement, natural studies, mathematics and drama. The music activity of singing songs was most frequently integrated with the field of dancing, fine-arts education and natural sciences, since the content of the song for children became the starting point for the integration with the mentioned areas of activity. Playing instruments was frequently integrated with the area of language and education in dancing, and listening to music was integrated with the field of fine-art education, language and dancing. The integration of listening to music with the field of fine-arts, language and dancing is from the didactic point of view necessary, since active listening to music guides the children towards the reproduction of the music contents in their inner image. The children wish to express their experiencing of the music piece and sound image also through movement, fine arts and verbal communication. They integrated creating music with the fields of fine-arts education and education in dancing, and the music-didactic games with the field of education in dancing and language. Music activities were thus frequently integrated with other fields of art, e.g. with language, fine arts and dancing. Hence they followed the global goals of arts education. In the analysis of the curriculum from the point of view of fields of activity (inter-subject integration), the realisation of the principles of horizontal connectedness was observed. Table 1 showed that the teachers integrated music activities with different areas of activity. They were accurate in accounting for the content aspect of the integration between different fields of activity. They paid less attention to the process aspect of integration, since in the planning of music activities they paid attention to the content more as an element of integration and not so much to the goals in the forming of which they were supposed to pay attention to the integration of the processes perception, experiencing and expression.

The educational process in the field of music education should be shaped as an integral, balanced process which does not allow uni-laterality in the sense of encouraging merely the emotional, cognitive and motor development. Emotional processes encourage activities in the cognitive and motor fields. And it is the interaction between the processes in the emotional, cognitive and motor fields that musical development is based on. 


\subsubsection{Extent to Which Different Goals Are Represented}

Table 2 showed that the pre-school teachers to a greater extent planned field-related goals of the curriculum and global goals of the curriculum defined for the field of the arts, while they paid lesser attention to music-subject goals, which they themselves had shaped, and the least attention to the general goal, which, too, they themselves formed. The pre-school teachers did not plan all the field-related goals equally with respect to representation. One of the reasons could be the absence of some of the field-related goals in the lessons plans of pre-school teachers in similar structures of goals. It is also interesting to note that the pre-school teachers mostly planned those filed-related goals which were in the curriculum for kindergartens listed at the very beginning of the curriculum. The quantitative relationship between the field-related goals and the remaining goals in the tables indicates that the teachers do not account for the principles of equal representation and professional justification. The plans pay greater attention to field-related goals and much less to music-subject goals in the formation of which they encountered difficulties most frequently. It is extremely important that the general and field-related goals are constantly accounted for in the planning, realisation and evaluation of the educational process. It is also necessary to be aware the danger that if in the case of music activities one exclusively follows the general and field-related goals of the curriculum, individual artistic fields could be deprived of their autonomy, which means that they could be replaced by other fields, e.g. pre-school teachers or pupils can choose from among singing, drawing, dancing...

\section{Conclusion}

The findings of the research show that the curriculum does not provide enough support for the pre-school teachers in the successful planning of the educational process of music education. The analysis of the planned curriculum

Table 1. Integration of music activities with areas of activity.

\begin{tabular}{|c|c|c|c|c|c|c|c|}
\hline \multirow{2}{*}{$\begin{array}{l}\text { Music activities } \\
\text { Fields of activity }\end{array}$} & \multirow{2}{*}{$\begin{array}{l}\mathrm{S} \\
\mathrm{f}\end{array}$} & \multirow{2}{*}{$\begin{array}{l}\mathrm{P} \\
\mathrm{f}\end{array}$} & \multirow{2}{*}{$\begin{array}{l}\mathrm{L} \\
\mathrm{f}\end{array}$} & \multirow{2}{*}{$\begin{array}{l}\mathrm{C} \\
\mathrm{f}\end{array}$} & \multirow{2}{*}{$\begin{array}{c}\text { MDG } \\
\mathrm{f}\end{array}$} & \multicolumn{2}{|c|}{ Total } \\
\hline & & & & & & $\mathrm{f}$ & $\mathrm{f} \%$ \\
\hline Movement & 38 & 15 & 35 & 16 & 10 & 114 & 12.9 \\
\hline Language & 36 & 26 & 36 & 20 & 22 & 140 & 15.9 \\
\hline Art: education in fine arts & 47 & 21 & 45 & 26 & 15 & 154 & 17.1 \\
\hline Education in dancing & 47 & 23 & 33 & 25 & 27 & 155 & 17.6 \\
\hline Education in drama & 13 & 5 & 6 & 7 & 4 & 35 & 3.9 \\
\hline Social studies & 35 & 20 & 27 & 16 & 17 & 115 & 13.7 \\
\hline Nature & 42 & 13 & 27 & 12 & 19 & 113 & 12.8 \\
\hline Mathematics & 13 & 11 & 7 & 9 & 14 & 54 & 6.1 \\
\hline Total & 271 & 134 & 216 & 131 & 128 & 880 & 100 \\
\hline
\end{tabular}

Interpretation of abbreviations in the table: $\mathrm{S}$ — singing songs, $\mathrm{P}$ - playing instruments, $\mathrm{L}$-listening to music, $\mathrm{C}$-creating in music, MDG-musical didactic games.

Table 2. Number (f) and structural percentage (f\%) of how all the planned goals are represented in the pre-school teachers' lesson plans.

\begin{tabular}{lcc}
\hline \multicolumn{1}{c}{ Goals } & f & f\% \\
\hline Field-related global goals of the curriculum & 235 & 25.3 \\
Field-related goals of the curriculum & 433 & 46.7 \\
General goals formed by the pre-school teachers & 59 & 6.4 \\
Music-subject goals formed by the pre-school teachers & 200 & 21.6 \\
Total & 927 & 100 \\
\hline
\end{tabular}


gives results which reveal that the pre-school teachers only partially realize individual principles of the curriculum and that the field of music education is in the planned curriculum losing its professional autonomy. Although the autonomy of individual art fields is in the history of the developments of curricula and even today linked with the philosophical dimension of the development of the curricula for music education or with the structure of the curriculum itself, it is necessary, irrespective of whether the field of music is in the curriculum defined as an independent field with stated general and operative goals and contents or as a constituent part of art as a field of activity, to ensure the general and specific characteristics of each art field. "Field-related goals defined in the curriculum encourage the interrelation and integration of individual art fields, they do not, however, guarantee them professional autonomy which is the condition for the existence of individual fields in the curriculum” (Denac, 2002).

The introduction of interdisciplinary connections is considered an upgrade of the subject-based approach and enables an in-depth comprehension of various topics. An interdisciplinary approach requires a high level of knowledge regarding individual fields that are to be connected, since such connections can only be successful if they do not suffocate the specific characteristics of these fields. This view is in line with Russell and Zembylas (2007, p. 297) who point out that "teachers feel uncomfortable when asked to teach in an integrated manner, unless they have had the opportunities to develop deeper knowledge in the subject they are trying to integrate”. At the same time, it is important to stress that professional education and training of teachers (also) in the field of interdisciplinary connections require continuous examination of scientific solutions in the process of life-long learning and the transposition of scientific data from theory into practice and vice-versa (Devjak \& Polak, 2007; Drake, 1998).

Even if the pre-school teachers in the planning of the educational process of music education take as starting point the thematic groups of topics and field-related global goals, they should nevertheless clearly define the goals of the professional field. It is important to know that only recognizing the autonomy of individual fields of art can ensure the integration of these into a poly-aestheticity at a higher level with the goal to develop a general sensitivity for cultural values. If the process of operative planning does not ensure the autonomy of the fields of art, this can result in the pre-school teachers for the realization of field-related goals to choose among those art fields they themselves have greatest interest in. And this will undoubtedly endanger the existence of individual art fields both in the curriculum and in the direct practice of carrying out the educational process. The findings of the research show that the curriculum does not provide enough support for the pre-school teachers in the successful planning of the educational process of music education. The analysis of the planned curriculum gave results which reveal that the pre-school teachers only partially realize individual principles of the curriculum and that the field of music education is in the planned curriculum losing its professional autonomy. Although the autonomy of individual art fields is in the history of the developments of curricula and even today linked with the philosophical dimension of the development of the curricula for music education or with the structure of the curriculum itself, it is necessary, irrespective of whether the field of music is in the curriculum defined as an independent field with stated general and operative goals and contents or as a constituent part of art as a field of activity, to ensure the general and specific characteristics of each art field. "Field-related goals defined in the curriculum encourage the interrelation and integration of individual art fields, they do not, however, guarantee them professional autonomy which is the condition for the existence of individual fields in the curriculum” (Denac, 2002).

The introduction of interdisciplinary connections is considered an upgrade of the subject-based approach and enables an in-depth comprehension of various topics. An interdisciplinary approach requires a high level of knowledge regarding individual fields that are to be connected, since such connections can only be successful if they do not suffocate the specific characteristics of these fields. This view is in line with Russell and Zembylas (2007, p. 297) who point out that "teachers feel uncomfortable when asked to teach in an integrated manner, unless they have had the opportunities to develop deeper knowledge in the subject they are trying to integrate”. At the same time, it is important to stress that professional education and training of teachers (also) in the field of interdisciplinary connections require continuous examination of scientific solutions in the process of life-long learning and the transposition of scientific data from theory into practice and vice-versa (Devjak \& Polak, 2007; Drake, 1998).

Even if the pre-school teachers in the planning of the educational process of music education take as starting point the thematic groups of topics and field-related global goals, they should nevertheless clearly define the goals of the professional field. It is important to know that only recognizing the autonomy of individual fields of 
art can ensure the integration of these into a poly-aestheticity at a higher level with the goal to develop a general sensitivity for cultural values. If the process of operative planning does not ensure the autonomy of the fields of art, this can result in the pre-school teachers for the realization of field-related goals to choose among those art fields they themselves have greatest interest in. And this will undoubtedly endanger the existence of individual art fields both in the curriculum and in the direct practice of carrying out the educational process.

\section{References}

Abbs, P. (1994). The Educational Imperative. London: Falmer Press.

Best, D. (1992). Generic Arts: An Expedient Myth. Journal of Art and Design Education, 11, 27-44. http://dx.doi.org/10.1111/j.1476-8070.1992.tb00686.x

Bevc, V. (2005). Interdisciplinary Planning and Connecting Educational Process. In T. R. Vec (Ed.), Encouraging the Active Role of Students in the Classroom (pp. 50-89). Ljubljana: Zavod Republike Slovenije za šolstvo.

Curriculum for Kindergartens. (1999). Ljubljana: Ministrstvo za šolstvo in šport.

Denac, O. (2002). The Role of Music in the Integral Development of the Child. Ljubljana: Zavod Republike Slovenije za šolstvo.

Denac, O., \& Čagran, B. (2012). Achieving the Objectives of Arts and Cultural Education in Slovenian Pre-Service Teacher Training. Creative Education, 8, 1419-1425. http://dx.doi.org/10.4236/ce.2012.38207

Devjak, T., \& Polak, A. (2007). Further Education and Training of Workers in the Field of Education. Ljubljana: Univerza v Ljubljani, Pedagoška fakulteta.

Dewey, J. (1934). Art as Experience. New York: Capricorn Books.

Drake, S. M. (1998). Creating Integrated Curriculum. California: Corwin Press, Inc.

Elliott, D. (1995). Music Matters: A New Philosophy of Music Education. New York: Oxford University Press.

Gardner, H. (1995). The Frames of Mind: The Theory of Multiple Intelligences. Ljubljana: Tangram.

Hargreaves, D. J. (1986). The Developmental Psychology of Music. Cambridge: Cambridge University Press. http://dx.doi.org/10.1017/CBO9780511521225

Moog, H. (1968). Das Musikerleben des Vorschulpflichtigen Kindes. Mainz: Schott.

Phenix, P. (1964). Realms of Meaning: A Philosophy of the Curriculum for General Education. New York: McGraw Hill.

Radoš-Mirković, K. (1983). The Psychology of Music Abilities. Beograd: Zavod za udžbenike i nastavna sredstva.

Reid, L. A. (1986). Ways of Understanding and Education. London: Heinemann.

Russell, J., \& Zembylas, M. (2007). Arts Integration in the Curriculum: A Review of Research and Implications for Teaching and Learning. In L. Bresler (Ed.), International Handbook of Research in Arts Education (pp. 287-302). Dordrecht: Springer. http://dx.doi.org/10.1007/978-1-4020-3052-9_18

Sicherl-Kafol, B. (2007). Process and Content Based Aspect of Interdisciplinary Connections. In J. Krek, T. Hodnik Čadež, J. Vogrinc, B. Sicherl-Kafol, T. Devjak, \& V. Štemberger (Eds.), Teacher as Researcher: Action Research in the Fields of Cross-Curricular Integration and Conception of Education in Public Schools (pp. 112-130). Ljubljana: Pedagoška fakulteta. 